IZA DP No. 8215

Positional Concerns among the Poor:

Does Reference Group Matter?

Evidence from Survey Experiments

Alpaslan Akay

Lisa Andersson

Peter Martinsson

Haileselassie Medhin

May 2014 


\title{
Positional Concerns among the Poor: Does Reference Group Matter? Evidence from Survey Experiments
}

\author{
Alpaslan Akay \\ University of Gothenburg and IZA \\ Lisa Andersson \\ University of Gothenburg \\ Peter Martinsson \\ University of Gothenburg \\ Haileselassie Medhin \\ University of Gothenburg
}

Discussion Paper No. 8215

May 2014

IZA

P.O. Box 7240

53072 Bonn

Germany

Phone: +49-228-3894-0

Fax: +49-228-3894-180

E-mail: iza@iza.org

\begin{abstract}
Any opinions expressed here are those of the author(s) and not those of IZA. Research published in this series may include views on policy, but the institute itself takes no institutional policy positions. The IZA research network is committed to the IZA Guiding Principles of Research Integrity.

The Institute for the Study of Labor (IZA) in Bonn is a local and virtual international research center and a place of communication between science, politics and business. IZA is an independent nonprofit organization supported by Deutsche Post Foundation. The center is associated with the University of Bonn and offers a stimulating research environment through its international network, workshops and conferences, data service, project support, research visits and doctoral program. IZA engages in (i) original and internationally competitive research in all fields of labor economics, (ii) development of policy concepts, and (iii) dissemination of research results and concepts to the interested public.
\end{abstract}

IZA Discussion Papers often represent preliminary work and are circulated to encourage discussion. Citation of such a paper should account for its provisional character. A revised version may be available directly from the author. 


\section{ABSTRACT}

\section{Positional Concerns among the Poor: Does Reference Group Matter? Evidence from Survey Experiments ${ }^{*}$}

Previous research suggests a lower degree of positional concerns among people from poor countries. Yet the evidence is limited and most often builds on the assumption that people's reference groups are the same across all individuals. We conduct a survey experiment in urban Ethiopia that is modified to include multiplicity of reference groups. We estimate positional concerns considering various reference groups to test whether the low positional concerns found in the literature is due to misspecification of the reference groups. The results show a low degree of positional concern which is highly stable across different reference groups.

JEL Classification: D60, C90

Keywords: reference groups, income comparison, experiment

Corresponding author:

Alpaslan Akay

University of Gothenburg

Vasagatan 1

40530, Gothenburg

Sweden

E-mail: alpaslan.akay@economics.gu.se

\footnotetext{
Financial support from the Formas through the program Human Cooperation to Manage Natural Resources (COMMONS) and from the Swedish Research Council (Vetenskapsrådet) is gratefully acknowledged.
} 


\section{Introduction}

Concerns about positionality (or status) have been widely discussed by many scholars, including Adam Smith and Karl Marx and later, e.g., Veblen (1899), Duesenberry (1949), and Hirsch (1976). In the last couple of decades, positional concerns for income or consumption have been hot topics in economics (Clark and Oswald, 1996; Frank, 1999; Akay and Martinsson, 2011). Positional concern implies that individuals compare their income or consumption level with "relevant other" individuals or groups of people. In other words, the utility that people derive from income or a good does not only depend on the absolute amount of income or goods consumed, but also on the amount of income or goods consumed relative to the amount of income earned or goods consumed by others. There is a growing empirical literature investigating positionality concerns in the context of optimal taxation (e.g., Boskin and Sheshinski, 1978.; Ljungqvist and Uhlig, 2000; Alpizar et al., 2005; Aronsson and Johansson-Stenman, 2008), labor supply (e.g., Neumark and Postlewaite, 1998; Woittiez and Kapteyn, 1998; Park, 2010), saving and investment (e.g., Abel, 1990; 2005), and migration (Knight and Gunatilaka, 2010; Akay et al., 2012b), to mention a few.

The impact of positional concern on individual utility has been studied using both survey experiments (e.g., Solnick and Hemenway, 1998; 2005; 2007; JohanssonStenman et al., 2002; Alpizar et al., 2005; Carlsson et al., 2007a; Akay et al., 2012a) and subjective well-being data (e.g., Clark and Oswald, 1996; McBride, 2001; 
Ferrer-i-Carbonell, 2005; Luttmer, 2005; Clark et al., 2008). The general conclusion from both approaches is that the utility is significantly and negatively affected by the income of others in rich developed Western countries. The studies on positional concerns in low-income countries presents more mixed results: a positive positional concern is reported by some studies reflecting tight community ties and altruistic preferences among the poor (e.g. Kingdon and Knight, 2007; Bookwalter and Dalenberg, 2009), while other studies find that the income of others does not significantly affect the utilities of the poor (e.g., Carlsson et al., 2007b; Ravallion and Lokshin, 2010; Akay and Martinsson, 2011; Akay et al., 2012a). ${ }^{1}$ Yet the evidence is very limited even though investigating positional concerns among poorer populations is very important since these concerns might have important links to poverty-alleviation interventions. This is particularly important given the fact that aid-financed interventions often target a certain group people based on some socioeconomic criteria. For example, offereing new agricultural technologies and advice to few 'model farmers' is a common practice in many poor countries. If positionality is strong among poor people, the targeting of aid projects could create welfare externalities, which could in turn hamper their success. Strong positional concerns may also lead to 'conspicuous consumption', thereby diverting scare resources from productive investments and saving.

One of the important issues in the studies of positionality is the choice of relevant others, or "reference group," with whom individuals make comparisons. The

\footnotetext{
${ }^{1}$ All papers except Akay et al. (2012) use subjective well-being aproach to measure positional concerns in the context of developing countries.
} 
concept of a reference group was first explored in studies of social psychology (Hyman, 1960; Runciman, 1966). Runciman (1966) emphasizes the role and importance of choice of reference group for estimates of positional concerns. He recognizes that an individual can also have multiple reference groups depending on the topic and context. However, the general approach used in the economic literature is to make a priori judgment of the composition of reference groups based on characteristics such as geographical proximity, age, education, race, and/or gender, without taking into account that all individuals do not necessarily share the same reference group, and that people could have several simultaneous reference groups that affect their utilities in different ways. Moreover, in the context of low-income countries, the reference groups may also have more complex structures since the members of the community might rely on informal insurance systems in the absence of more formal insurance mechanisms. There is vast evidence showing that people in developing countries often form informal insurance and risk-sharing networks based on close geographic proximity and kinship (e.g., de Weerdt and Dercon, 2006; Fafchamps and Gubert, 2007). Within such informal arrangements, households may be positively affected by an income increase of other households in their network, which in turn implies that the choice of reference group is important and the degree of positionality may vary depending on how the reference group is specified. Thus, the lower degree of positionality often found in the literature may simply be an artifact of the construction of reference groups similar to those used for rich developed countries. The objectives of this study are twofold. First, we investigate the positional concerns of the poor using survey experiments to bring new evidence 
to the literature. Second, we address the issue of multiple or simultaneous reference groups among the poor by relaxing the assumption that everyone compares their own income with only one single reference group. We do this by exploring positional concerns relative to an array of possible reference groups defined using different comparison orbits of social proximity.

The survey experiment was conducted among 260 randomly selected residents of Addis Ababa, the capital city of Ethiopia. The experimental nature of our study allows us to specify different reference groups that are believed to represent key social groupings presumed to exist in every society, and investigate how positional concerns differ across reference groups among the poor. We control for six reference groups - friends, neighbors, relatives, colleagues, people of the same age, and all other people in the city. These groups are defined based on different physical and social comparision orbits that we believe the respondents are likely to have interaction and common attributes with, and that have been proposed and used as relevant points of reference in other studies (e.g., Carlsson et al., 2009; Knight et al., 2009; Clark and Senik, 2010a; Carlsson and Qin, 2010).

The results obtained in our analysis can be summarized as follows: We find very low positional concerns for each reference group compared to estimates from developed countries, confirming previous results from rural Ethiopia in Akay and Martinsson (2011) and Akay et al. (2012a). There is some heterogeneity in positional concerns across different reference groups, but again, even the highest 
marginal degree of positionality is much lower than the average from developed countries. In our econometric analysis, which controls for various individual sociodemographic and economic characteristics, we find that the positional concerns visà-vis friends, neighbors, relatives, colleagues and all other people in the city are not statistically significantly different from zero though there is some variation. The positional concerns are somehow higher and statistically significant when people compare their income with people of the same age. We also report that the positional concerns are heterogeneous across some socio-demographic and economic characteristics of individuals. Marital status and education seem to be the most important socio-economic determinants of positional concerns.

The remaining part of the paper is organized as follows: The next section discusses previous literature on positional concern and the issue of reference group. Section 3 gives the experimental design. Section 4 presents the results using interval regressions. We also estimate the mean degree of positionality using bootstraping conditional on the socio-dempographic characteristics of the individuals. Section 5 discusses the implications of the results and concludes the paper.

\section{Positional concerns and reference groups: what do we know?}

\subsection{Methods and literature}

Empirical investigation of positionality in the literature draws on two distinct approaches. The first approach is based on survey experiments to directly identify 
the degree to which individuals care about absolute and relative income or consumption by asking individuals to choose between different societies in which they prefer to live, where the societies differ in the individual's own and others' average level of income. The overall results from these survey experiments show that people do have positional concerns both for income and for consumption of specific goods, but that the degrees vary by goods and location (see Solnick and Hemenway, 1998; 2005; 2007; Johansson-Stenman et al., 2002; Alpizar et al., 2005; Carlsson et al., 2007a; 2007b; 2009; 2010; Akay et al., 2012a for experimental findings). ${ }^{2}$ A second, parallel, approach is based on self-reported subjective wellbeing data, collected through "happiness" or "life satisfaction" questions in surveys. The impact of positionality on subjective well-being is then investigated using relative income, which is defined as the mean (or median) income level of the reference group ${ }^{3}$. The general welfare implication obtained from studies conducted in rich Western countries is that people care about other people's income, and that subjective well-being is negatively affected by the income of others (Clark and Oswald, 1996; McBride, 2001; Senik, 2005; Ferrer-i-Carbonell, 2005).

However, the literature examining positional concern in transition and developing economies is limited and the results are more mixed (see Clark and Senik, 2010b for

\footnotetext{
2 Positionality has also been investigated in controlled laboratory experiments (e.g., Clark et al., 2010; McBride, 2010).

${ }^{3}$ Most of these studies use an objective measure (such as the income compared to the mean income of the reference group) to determine an individual's relative position. It has however been shown that the results may vary depending on whether objectives or subjective (e.g. an individual's perception of its own ranking in the income distribution) measures are used (Posel and Casale, 2011). The distinction between subjective and objective measures of relative position is however less important in the experiment approach used in this survey.
} 
a comprehensive review). Akay et al. (2012a) conduct a survey experiment - similar to the one in this paper - among very poor rural Ethiopian farmers. They find very low positionality for income in general and for the income obtained from an aid project. Using a similar survey experiment, Carlsson et al. (2007b) find low degree of positionality among farmers in rural Vietnam, while a higher degree of positionality is found by Carlsson and Qin (2010) among farmers in rural China. Results from studies using the subjective well-being approach in low-income countries are in line with those found using survey experiments. Ravallion and Lokshin (2010) investigate relative income effects in Malawi and find that relative comparison does not seem to matter for most of the sample, but for the relatively well-off (including those living in urban areas) subjective well-being does seem to fall with average neighborhood income. A similar result is found by Akay and Martinsson (2011) for rural farmers in Ethiopia. They use subjective well-being data and various alternative ad hoc reference groups and show that the mean income level of the reference groups does not significantly affect the well-being of poor rural farmers in Ethiopia. In contrast, Fafchamps and Shilpi (2008) use data from Nepal to test whether poor and more isolated households care less about relative consumption, and find that relative consumption negatively affects subjective wellbeing even at low absolute or relative levels of consumption.

Some evidence obtained from the subjective well-being approach contrasts the finding from developed countries and shows positive effects of income comparisons in developing and transition economies. Kingdon and Knight (2007) find neighbors 
to be positive rather than negative comparators, and that subjective well-being rises with average income in the immediate neighborhood in South Africa. This result is confirmed by another study from South Africa by Bookwalter and Dalenberg (2009), who find that at low levels of income and expenditures the benefit of living among wealthier people outweighs the negative effect of being the poorest in a peer group. The positive effects of higher income of others found in some studies are in line with the "tunnel effect" conjectured by Hirschman and Rothschild (1973). An increase in the income of the reference group is interpreted as an encouraging prospect of future income gains. In poorer contexts, risk-insurance mechanisms, altruistic preferences, and fellow feelings in the community have been suggested as the main explanations of the positive relative income effect (Kingdon and Knight, 2007).

\subsection{What is really a reference group?}

A crucial aspect in the studies of postional concerns is the specification of a reference group. The term "reference group” was first used by Hyman, though the idea behind the concept can be traced much further back in time in the literature and tradition of thoughts in social psychology (Hyman, 1960). Hyman highlights the difficulties of pre-judging the reference group that people use as their social framework for comparison, and argues in favor of empirically determining the reference group that people are likely to employ (Hyman, 1960, p.390). It is suggested in the literature that people make active choices when it comes to 
reference groups to serve self-relevant goals such as self-enhancement and selfimprovement. Self-enhancement refers to a strategy of downward comparison where the indiviudal compares himself with people who are less fortunate in order to feel better about their own set, while self-improvement refers to upward comparison where people compare themselves with indiviudals who perform better or are more fortunate in order to enhance one's own motivation and performance (see e.g., Falk and Knell, 2004 for a more detailed discussion). Despite the mounting evidence on the importance of positional concerns in economic decisions, most economic studies, whether they use a survey experiment or a subjective well-being method, suffer from a lack of information about the relevant reference groups and how these reference groups are formed. The reference group is almost always assumed to be exogenously given, and most often assumed to be the same across all individuals. The common approach in subjective well-being studies is to include one single reference group, refined using various socio-demographic characteristics (e.g., the same age cohort as in McBride, 2001; the same geographical area as in Blanchflower and Oswald, 2004 and Luttmer, 2005; the same region, education level, and age as in Ferrer-i-Carbonell, 2005). Among other things, such an approach could pose a challenge in the interpretation and use of positionality estimates if the specified reference group is not the relevant comparator. People could also have multiple reference groups simultaneously, and hence exhibit different levels of positional concerns vis-à-vis different reference groups. The issue of multiple reference standards therefore poses a serious challenge to the empirical investigation 
of positional concerns if survey and experimental instruments fail to fully capture an individual's reference group spectrum.

We are only aware of four studies (Carlsson et al., 2009; Knight et al. 2009; Clark and Senik, 2010a; Carlsson and Qin, 2010) that investigate potential reference groups by explicitly asking people with whom they compare themselves. Clark and Senik (2010a) investigate the degree of income comparison using the third wave of the European Social Survey covering 18 European countries. The survey asks people who they are most likely to compare their income with. Of those who identified a reference group, ${ }^{4}$ 36\% stated that they are most likely to compare their income with colleagues, $15 \%$ with friends, $6 \%$ with family members, and $7 \%$ with others. The choice of reference group was shown to be closely related to regular social interactions. Knight et al. (2009) use data from rural China where the respondents were directly asked who they compare themselves with. The most common comparator group was people in the village (40\%) followed by neighbors (29\%), while $7 \%$ compare themselves to relatives. Only $11 \%$ had a reference group outside the village (i.e., people in the township, county, city, or elsewhere in the country). When asking respondents in their experiment in rural China about their reference groups for income comparisons, Carlsson and Qin (2010) found small differences across the suggested reference groups, yet found neighbors, people in the village, and off-farm migrants in the city to be the most likely comparison groups, and people in the township or city to be the least likely comparison groups. Carlsson et

\footnotetext{
${ }^{4}$ About one third of the respondents, 36\%, stated that they do not compare their income.
} 
al. (2009) investigate and quantify the degree of positionality within and between castes in India using a sample of university students. Their results show that the negative effect on an individual's utility from an average increase in income in her own caste is larger than the positive effect on utility from an increased income of her own caste compared to the income of other castes.

A few studies also look at a set of different reference groups in order to assess the relative impact of different types of comparisons. Senik (2009) investigates the relative importance of internal and external comparison on well-being in all countries in the former socialist bloc, and finds internal comparison to one's own past living standard to outweigh all external comparison groups (parents, former colleagues, and high school friends). External comparison is however found to be more important than individuals' self-ranking in the social ladder. No clear-cut results are found with respect to the relative importance across external comparison groups, but former colleagues and schoolmates seem to play an equally important role, outweighing comparisons with one’s parents. Kuegler (2009) investigates the effect of relative income against various reference groups (siblings, friends, own past income, and parents' living standards in the past) using perceived relative income from Venezuela. Siblings turn out to be negative comparators, while no statistically significant results are found for any of the other reference groups. Kingdon and Knight (2007) test two different reference groups based on spatial proximity (neighbors) and social proximity (same race), and find that neighbors are positive comparators while a higher income in a reference group consisting of 
people of the same race has a negative effect on subjective well-being. Akay et al. (2012b) find that the well-being of Chinese rural-to-urban migrants depends on several reference groups and that well-being is positively affected by the income of urban workers but negatively affected by the income of other migrants and workers from the home region. Taken together, the results from these studies suggest in different ways that the choice of reference group matters for the direction and magnitude of positional concerns.

\section{Experimental Design}

\subsection{Setup}

To test for positional concern across different reference groups, we constructed six versions of the survey experiment where individuals' own income was compared to the income of friends, neighbors, relatives, colleagues, people of similar age, and all other people in the city. For each reference group, subjects were presented with a scenario describing two states of the world, referred to as societies, which only differ in the monthly income of the subject and the average monthly income of the people in the reference group in question. Subjects were then asked to choose in which of the two societies they would prefer to live. The income was expressed in the local currency Ethiopian Birr (ETB) and the official exchange rate was US\$ $1=$ ETB 16.80 at the time of the survey (see Appendix for the details of the instructions). 


\subsection{Preferences: modeling positional concerns}

There are various ways to empirically specify the utility function to allow for positional concerns. The most common specifications are (i) the ratio comparison utility function, $U=v(x, x / \bar{x})$, where $x$ is the individual's income and $\bar{x}$ is the average income in the reference group (e.g., Boskin and Sheshinski, 1978; Layard, 1980; Persson, 1995) and (ii) the additive comparison utility function, $U=v(x, x-\bar{x})$ (e.g., Akerlof 1997; Knell 1999; Ljungqvist and Uhlig, 2000). In this paper we apply the following additive comparison utility function:

$$
\begin{gathered}
v=(1-\gamma) x+\gamma(x-\bar{x}) \\
0 \leq \gamma \leq 1,
\end{gathered}
$$

where $\gamma$ measures the marginal degree of positional concern, i.e., the proportion of the total change in utility related to an increase in relative income when an individual's own income is marginally increased.

\subsection{The marginal degree of positional concern}

To elicit the degree of positionality, or more correctly the positionality interval, for each individual, respondents are asked to make pair-wise choices between societies that differ in own and others' income levels for all six reference groups. The income levels in each choice set for each reference group are systematically constructed to 
measure the degree of positionality. Starting from a choice with the lowest degree of positionality, individuals are presented with up to six successive choices until the respondent switches to the choice where she cares more about the absolute income than the relative income.

An example scenario used in the experiment is presented in the Table A1 in Appendix A. In the beginning, the individual chooses between a Society $A$ where her monthly income is lower than the average monthly income of the reference group, and a Society $B_{1}$ where her monthly income is higher than the average monthly income of the reference group but lower than her income in Society A. If the individual chooses $A$, the experiment for the specific reference group stops since the individual has revealed her actual interval of positionality, i.e., lower than the implied degree of positionality. If the individual chooses $B_{1}$, she is asked to choose between Society $A$ and Society $B_{2}$, where her income is further lower than in $B_{1}$, but still higher than the income level of the reference group, which is the same as in $B_{1}$. For instance, for the example choice scenario in the Table A1 with 'friends' as a reference group, the individual has an income of 640 Birr per months in Society A while the average income of her friends is 720 Birr. On the other hand, her income is 616 Birr in Society $B_{1}$ and that of that of her friends is 480 Birr. Her income decreases by 24 Birr in Society $B_{2}$ while the average income of her friends stays at 480 Birr. The 24 Birr decrease continues until $B_{6}$, where the individual's monthly income drops to 496 Birr. Since the choice is always against Society $A$, the degree of 
positional concern increases as we go from Society $B_{i}$ to Society $B_{i+1}$. The session ends if the individual chooses Society $A$ or has reached the last choice set $\left(B_{6}\right)$.

When the subject is indifferent between Society $A$ and Society $B_{i}$, then we know that

$$
x_{i, A}-\gamma \bar{x}_{A}^{r}=x_{i, B}-\gamma \bar{x}_{B}^{r} .
$$

Using equation (2), we can then calculate the marginal degree of positional concern from the choice between $A$ and $B_{1}$ in Table A1:

$$
\gamma=\frac{x_{A}-x_{B}}{\bar{x}_{A}^{r}-\bar{x}_{B}^{r}}=\frac{640-616}{720-480}=0.1
$$

When the subject chooses Society A (for this example), then it implies that the subject has a degree of positionality lower than $0.1(\gamma<0.1)$. We present repeated choices between the two societies. Using the stopping choice set (when the subject chooses Society A), we calculate the degree of positional concern of each individual within an upper and lower bound.

The reference groups used are presented in a subsequent order for each respondent. Since the survey experiment contains six reference groups presented one after the other, there is a possibility of order effect in their responses, which can be caused by learning, fatigue or wish to be consistent, or a combination of them. In order to limit 
biases that may arise from these effects, we randomized the order in which the reference groups were presented. It could be argued that the choice sets within a reference group should also be randomized, but we argue that this could create a very high cognitive burden and potentially also confusion for indiviuals, and hence we decided to refrain from this. Another design issue relates to which income levels to use in the choice sets. We thought that using the same income levels across reference gropus may induce individuals to try to be consistent. Thus, we decided to choose slightly different income levels, all just above subsistance level. Table 1 presents the full summary of the experiment. Note that even though the income levels are different in each choice set, the implicit degree of postitionality is the same across reference groups, changing between 0.1 and 0.6. Also note that the average income across the six reference groups in Society $A$ is close to 860 Birr per month, which is about 3.77 PPP Dollars per day. This is higher than commonly used poverty lines (e.g., 2 PPP Dollars per day). The lowest possible income in our choice scenarios is 480 Birr per month (2.1 PPP dollars per day), which is also just above the 2 Dollar poverty line. That is, even the income level associated with the highest level of positionality in the experiment in any of the reference groups is above the poverty line. It should also be noted that the income levels in the experiment are presented as individual incomes of the respondent, not as the total income of their household.

Table 1 about here 
The experiment was conducted among 260 individuals in Addis Ababa, Ethiopa. The mean per-capita daily income of the households in the sample is 3.79 PPP dollars, which is very close to the average income used in the experiment ( in average 3.77 PPP Dollars per day). Close to $59 \%$ of the respondents are male and about $37 \%$ are married. The average age in our sample is 44 years. Moreover, about $39 \%$ have gone through highschool education or more. We employed five local interviewers, who received training prior to the experiment. We conducted a face-toface interview with each subject in the local language (Amharic). To ensure consistency, the instructions were first translated to the local language and then translated back to English by two different individuals. The experiment was took place within the framework of a larger household survey, and the respondents originate from a sub-sample of households included in the Ethiopian Urban Socioeconomic Survey (EUSS). ${ }^{5}$ After the experiment had been conducted, the respondents participated in a household survey that collected additional socioeconomic information about the subjects..

\section{Results}

As discussed in the previous section, the key measure in our empirical investigation is the marginal degree of positionality. We start by presenting a descriptive analysis of the unconditional mean marginal degree of positionality. We then estimate the

\footnotetext{
${ }^{5}$ The EUSS covers seven urban cities in Ethiopia and originally included 1500 households. A random sample of households from five sub-cities in Addis Ababa (Addis Ketema, Kirkos, Arada, Yeka and Gullele) were sampled for the purpose of this experiment. None of the included sub-cities are considered to be particularly rich or poor in the city. The number of households in each sub-city was chosen proportionally to the number of households included in each sub-city in the panel survey.
} 
mean marginal degrees of positionality for different reference groups by using econometric models conditional on individual characteristics.

\subsection{Descriptive analysis}

By using the design features presented in Table 1, we can calculate the unconditional mean marginal degree of positionality. Table 2 summarizes the frequency distributions of marginal degree of positionality intervals across the six reference groups. As can be seen from the table, most people chose Society $A$ in the first choice set. Almost two-thirds of the subjects displayed a very low degree of positionality for each reference group. We can conclude from these results that regardless of which reference group we consider, the unconditional degree of positionality is very low in our sample, which is in line with the existing findings in the literature. There could however be heterogeneity across socio-demographic and economic characteristics of the individuals, which we investigate in more detail below.

Table 2 about here

To estimate the mean marginal degree of positionality, we assume that the actual value of the positionality for each individual lies in the middle of each positionality interval. Note that our design cannot identify the maximum or minimum positional concerns. We have to make some assumptions. The mid-value for the highest 
positional concern is assumed to be 0.8 by considering that the maximum positional concern is 1 , and the mid-value of the lowest positional concern is assumed to be 0.05 by considering that the lowest positional concern is $0 .{ }^{6}$ The unconditional mean marginal degrees of positionality are presented in the Table 3, together with the standard deviations and confidence intervals.

Table 3 about here

The mean marginal degrees of positionality estimates are found to be very small, as expected from the descriptive statistics given above. These results are highly in line with Akay and Martinsson (2011) and Akay et al. (2012a), who find very low positionality estimates in rural Ethiopia. We are mainly interested in the relative difference between the positionality parameters across reference groups. The lowest positionality estimate is obtained when subjects compare their income with their relatives, which could be due to strong family relationships and possible altruism between extended family members. The highest positionality is found vis-à-vis neighbors. We compare the experimental data pairwise using t-tests. We find significant differences in the positionality across reference groups. Test results for the mean difference suggest that the difference is statistically significant in the case of positionality experienced toward neighbors and relatives ( $\mathrm{p}$-value $=0.031$ );

\footnotetext{
${ }^{6}$ We have also experimented with some other lower and upper limits. The result is basically the same.
} 
neighbors and same age people (p-value=0.099); and neighbors and all other people in Addis (p-value $=0.027){ }^{7}$

\subsection{Results by socio-demographic characteristics}

We investigate which factors explain the degree of positional concern for each reference group using regression analyses. Our dependent variable of interest is the marginal degree of positionality. The experimental setup gives us a dependent variable with a lower and an upper bound, and thus we use an interval regression specification. The lower and upper bounds of the intervals are specified as in the first column of Table 2. As before, we have to make some assumptions for the extreme choices. We assign 0 for the lower bound of the first interval and 1 for the upper bound of the last interval.

In our regressions, we control for various exogenous variations: age, gender, marital status, occupation, household size, education, migrant status, household income, location in Addis Ababa, and ethnic groups (the locations in our sample are the sub cities Kirkos, Arada, Addis Ketama, Yeka, and Gullele; ethnic groups are Amhara, Oromo, Tigray, and Others). Table 4 reports interval regression estimates. The

\footnotetext{
${ }^{7}$ It was rightly pointed out to us by an anymous referee that our choice scenioro is not designed to capture very small differences bewteen the positional concerns towards difference reference groups. For example, we are not able to see differences within the $(0,0.1]$ interval where the majority of choices for all references groups lie. Picking up such small differences would have required adding more choices of $B_{i}$ between $A$ and the current $B_{1}$, there by signifinatly increasing the number of choices that people make. We believe this would have been congnitively demanding for respondends. It also should be noted that such refininement would not have a major effect on the main result that the degree of positional concerns are very low for all reference groups.
} 
variation in the marginal degree of positionality is explained by several variables. For example, female subjects are more positonal vis-à-vis people of the same age, and single subjects are less positional toward all reference groups except for people of the same age.

Table 4 about here

\subsection{Estimating conditional degree of positionality}

One of our aims is to use estimated regression parameters presented above to estimate the mean degree of positional concern conditional on socio-demographic and economic characteristics of the subjects. To calculate the mean degree of positional concern as well as confidence intervals, we use the bootstrap technique (see, e.g., Efron and Tibshirani, 1998). We first predict the marginal degree of positionality for each individual using estimated model parameters and then calculate the mean level of predicted marginal degree of positional concerns for each bootstrap sample, which is conditional on the socio-demographic and economic characteristics of the subjects. This procedure is repeated for 1,000 bootstrap samples. Table 5 presents the conditional mean marginal rate of positionality for the overall sample and for the selected socio-demographic groups. Results are presented for each of the reference groups separately. Again, it is clear from Table 5 that the positional concerns are very low. The fact that most estimates are insignificant indicates that, conditional on observed individual characteristics, positional concerns

are basically zero. The only statistically significant mean marginal degree of 
positionality is obtained for the reference group people of the same age. Significant estimates toward this reference group are also found for four of the sociodemographic groups. However, the level of the positionality is much lower than that is found in developed countries.

Table 5 about here

We also control for the order effect with 12 different combinations of the experimental design. However, in order to check the sensitivity of the results we include dummies for the order categories in the interval regressions. We estimate the marginal degree of positionality using 1,000 bootstrap replications. The results are not reported here since they are virtually the same as the results presented in Table $5^{8}$

\section{Discussions and Conclusion}

In this paper we have estimated the marginal degree of positional concern of poor people in an urban setting using various reference groups explicitly introduced into a survey experiment, to our knowledge first time in the literature. We conduct our experiment among 260 individuals living in urban Ethiopia by modifying existing survey experiments used in the literature. The results indicate that positional

\footnotetext{
${ }^{8}$ We also estimated the mean marginal degree of positionality using Spearman-Karber, which is a nonparametric estimator. This estimator is robust to sample size. In this estimator the data is interpreted as a failure or duration time data. The results obtained from this experiment is highy in line with the results reported in Table 5 . The results can be provided upon request from the corresponding author.
} 
concerns are low in societies with low absolute level of income. While there are differences across reference groups, the low positionality for income persists vis-àvis all reference group definitions.

Our results suggest that the only significant estimate of the marginal degree of positionality is toward the reference group people of the same age. While the marginal degree of positionality is still low, the fact that the "same age" reference group stands out from the other reference groups could have interesting implications when it comes to the role of social proximity, informal mechanisms, and positional concerns. The insignificant estimates found for positional concerns toward the reference groups relatives, friends, neighbors, and colleagues may be explained by relationship attributes, e.g., altruism and informal support systems, that imply low positional concerns toward reference groups. There is no meaningful way age similarity could be used as a network formation mechanism, while it is reasonable to think that people compare their achievements with those of others of similar age, resulting in significant income comparison estimates. On the other hand, the reference group all other people in the city could be too intangible to the individual to make meaningful comparisons.

In this paper, we have systematically investigated positional concerns toward multiple reference groups using a survey experiment approach. Our results add to the growing evidence showing that positional concerns are low in societies with low absolute level of income for almost all reference groups that we defined. This 
indicates that development interventions that target few people create little welfare externalities. But the inverse relationship between positional concerns and overall absolute income level of a society raises another important question for the design of development interventions: is it possible to increase income of a society without developing positional concerns or are positional concerns inherent to economic growth? More work remains to be done to explain the relationship between economic growth and positional concerns, and understand the underlying relationships between reference groups and degree of positionality. In particular, there is a need for future research to understand how these relationships are shaped by the socio-economic proximity generated through informal mechanisms between individuals in low-income countries.

\section{References}

Abel, A.B., (1990) Asset Prices Under Habit Formation and Catching Up with the Joneses, American Economic Review 80, 38-42.

Abel, A.B., (2005) Optimal Taxation When Consumers Have Endogenous Benchmark Levels of Consumption, Review of Economic Studies 72, 21-42.

Akay, A., P. Martinsson and H. Medhin, (2012a) Does Positional Concern Matter in Poor Societies? Evidence from a Survey Experiment in Rural Ethiopia, World Development 40, 428-435.

Akay, A., O. Bargain, and K.F. Zimmermann, (2012b) Relative Concerns of Ruralto-Urban Migrants in China, Journal of Economic Behavior and Organization 81, 421-441.

Akay, A., and P. Martinsson, (2011) Does Relative Income Matter for the Very Poor? - Evidence from Rural Ethiopia, Economic Letters 110, 213-215.

Akerlof, G.A., (1997) Social Distance and Social Decisions, Econometrica 65, 1005-1027. 
Alpizar, F., F. Carlsson and O. Johansson-Stenman, (2005) How Much Do We Care about Absolute versus Relative Income and Consumption?, Journal of Economic Behavior and Organization 56, 405-421.

Aronsson, T., and O. Johansson-Stenman, (2008) When the Joneses' Consumption Hurts: Optimal Public Good Provision and Nonlinear Income Taxation, Journal of Public Economics 92, 986-997.

Blanchflower, D.G., and A.J. Oswald, (2004) Well-being Over Time in Britain and the USA, Journal of Public Economics 88, 1359-1386.

Bookwalter, J., and D.R. Dalenberg, (2009) Relative to What or Whom? The Importance of Norms and Relative Standing, World Development 38, 345-355.

Boskin, M.J., and E. Sheshinski, (1978) Individual Welfare Depends upon Relative Income, Quarterly Journal of Economics 92, 589-601.

Carlsson F., G. Gupta, and O. Johansson-Stenman, (2009) Keeping up with the Vaishyas: Caste and relative standing, Oxford Economic Papers 61, 52-73

Carlsson, F., O. Johansson-Stenman, and P. Martinsson, (2007a) Do You Enjoy Having More than Others? Survey Evidence of Positional Goods, Economica 74, 586-598.

Carlsson, F., P. Nam, M. Linde-Rahr and P. Martinsson, (2007b) Are Vietnamese Farmers Concerned with Their Relative Position in Society?, Journal of Development Studies 43, 1177-1188.

Carlsson, F. and P. Qin, (2010) Is it better to be the head of a chicken than the tail of a phoenix: Concern for relative standing in rural China, Journal of SocioEconomics 39, 180-186.

Clark, A.E., and A.J. Oswald, (1996) Satisfaction and Comparison Income. Journal of Public Economics 61, 359-381.

Clark, A.E., and C. Senik, (2010a) Who Compares to Whom? The Anatomy of Income Comparisons in Europe, Economic Journal 120, 573-594.

Clark, A.E., and C. Senik, (2010b) Will GDP Growth Increase Happiness in Developing Countries, IZA Discussion Paper Series, No: 5595.

Clark. A.E., D. Masclet, and M.-C. Villeval, (2010) Effort and comparison income, Industrial and Labor Relations Review 63, 407-426.

Clark, A.E., P. Frijters and M.A. Shields, (2008) Relative Income, Happiness and Utility: An Explanation for the Easterlin Paradox and Other Puzzles, Journal of Economic Literature 46, 95-144.

de Weerdt, J., and S. Dercon, (2006) Risk-sharing networks and insurance against illness, Journal of Development Economics 81, 337-356.

Duesenberry, J., (1949) Income, Saving and the Theory of Consumer Behavior, Cambridge MA: Harvard University Press. 
Efron, B., and R.J. Tibshirani (1998) An Introduction to the Bootstrap, Chapman and Hall, Florida (1998)

Fafchamps, M., and F. Guberg (2007) The Formation of Risk Sharing Networks, Journal of Development Economics 83, 326-350.

Fafchamps, M and F. Shilpi (2008) Subjective welfare, isolation, and relative consumption, Journal of Development Economics 86, 43-60.

Falk, A. and M. Knell, (2004) Choosing the Joneses: Endogenous Goals and Reference Standards, Scandinavian Journal of Economics 106, 417-435.

Ferrer-i-Carbonell A. (2005) Income and Well-Being: An Empirical Analysis of the Comparison Income Effect, Journal of Public Economics 89, 997-1019.

Frank, R.H., (1999) Luxury Fever. Free Press, New York.

Hyman, H.H., (1960) Reflections on Reference Groups. Public Opinion Quarterly 24, 383-396.

Hirsch, F., (1976) Social Limits to Growth. Harvard University Press, Cambridge.

Hirschman, A., and M. Rothschild, (1973) The changing tolerance for income inequality in the course of economic development, Quarterly Journal of Economics 87, 544-566.

Johansson-Stenman, O., F. Carlsson, and D. Daruvala, (2002) Measuring Future Grandparents' Preferences for Equality and Relative Standing, Economic Journal 112, 362-383.

Kingdon, G. and J. Knight, (2007) Community, comparisons and subjective wellbeing in a divided society, Journal of Economic Behavior and Organization 64, 69-90

Knell, M., (1999) Social Comparisons, Inequality, and Growth, Journal of Institutional and Theoretical Economics 155, 664-695.

Knight, G., L. Song, L. and R. Gunatilaka, (2009) Subjective well-being and its determinants in rural China, China Economic Review 20, 635-649.

Knight, J. and R. Gunatilaka, (2010) Great expectations? The Subjective Well-being of Rural-Urban Migrants in China, World Development 38, 113-124.

Kuelger, A., (2009) A Curse of Comparison? Evidence on Reference Groups for Relative Income Concerns, World Bank Policy Research Working Paper 4820.

Layard, R., (1980) Human Satisfaction and Public Policy, Economic Journal 90, 737-750.

Luttmer, E.F.P., (2005) Neighbors as Negatives: Relative Earnings and Well-Being, The Quarterly Journal of Economics 120, 963-1020.

Ljungqvist, L. and H. Uhlig. (2000) Tax Policy and Aggregate Demand Management under Catching Up with the Joneses, American Economic Review 90, 356-366. 
Neumark, D., and A. Postlewaite, (1998) Relative Income Concerns and the Rise in Married Women’s Employment, Journal of Public Economics 70, 157-183.

McBride, M., (2010) Money, happiness, and aspirations: An experimental study, Journal of Economic Behavior and Organization 74, 262-276.

McBride, M., (2001) Relative-Income Effects on Subjective Well-Being in the Cross-Section, Journal of Economic Behavior and Organization 45, 251-278.

Park, Y., (2010) The Second Paycheck To Keep Up with the Joneses: Relative income concerns and labor market decisions of married women, Eastern Economic Journal 36, 255-276.

Persson, M., (1995) Why Are Taxes So High in Egalitarian Societies? Scandinavian Journal of Economics 97, 469-476.

Posel, D., and D. Casale, D., (2011) Relative standing and subjective well-being in South Africa: The role of perceptions, expectations and income mobility. Social Indicators Research 104, 195-223.

Ravallion, M. and M. Lokshin, (2010) Who cares about relative deprivation?, Journal of Economic Behavior \& Organization 73, 171-185.

Runciman, W.G., (1966) Relative comparison and Social Justice: a study of attitudes to social inequality in twentieth-century England, Routledge and Kegan Paul.

Senik, C., (2005) Income Distribution and Well-being: What can we learn from Subjective Data?, Journal of Economic Surveys 19, 43-63.

Senik, C., (2009) Direct Evidence on Income Comparisons and Their Welfare Effects. Journal of Economic Behavior and Organization 72, 408-424.

Solnick, S., and D. Hemenway, (1998) Is More Always Better? A Survey on Positional Concerns, Journal of Economic Behavior and Organization 37, 373383.

Solnick, S., and D. Hemenway, (2005) Are Positional Concerns Stronger in Some Domains Than in Others?, American Economic Review 95, 147-151.

Solnick , S., and D. Hemenway, (2007) Positional Goods in the United States and China, Journal of Socio-Economics 36, 537-545.

Veblen, T., (1899/2005) The Theory of the Leisure Class. Digireads.com.

Woittiez, I., and A. Kapteyn, (1998) Social Interactions and Habit Formation in a Model of Female Labour Supply, Journal of Public Economics 70, 185-205. 


\section{$\underline{\text { Appendix A }}$}

\section{Experiment instructions}

Now I want to ask you some questions related to income.

Imagine that you can choose to live in one of two different societies, Society A and Society B. Your monthly income and the average monthly income of different groups of people differ between the two societies. Except for the income differences, other things like living expenses are exactly the same in the two societies.

For each society that we will consider, I will tell you the amount of your monthly income and the average monthly income of the group. Then I will ask you to choose which society you would like to live in.

Let me illustrate this choice by the following example. In this example, we will just name the group of people "other people."

\begin{tabular}{|l|c|c|}
\hline Society & $\begin{array}{c}\text { Your own income } \\
\text { Birr/Month }\end{array}$ & $\begin{array}{c}\text { Average income of } \\
\text { Other people } \\
\text { Birr/Month }\end{array}$ \\
\hline Society A & $\mathbf{8 0 0}$ & 900 \\
\hline Society B & 770 & 600 \\
\hline Which society do you choose to live in?
\end{tabular}

In this example, your yearly income is 30 birr more in Society A than in Society B. In Society A, you earn 100 birr less than the average income of other people in the society, while in Society B you get 170 birr more. Given these differences, you can either choose to live in Society A or B. (Repeat question and example)

Now, I'll ask you to make your choice between the different societies.

(For each table of a reference group, ask the first questions in the following way. Do not change the order the tables from what is given in this questionnaire! )

In Society A, your monthly income is birr, while the average monthly income of __ in the society is birr. In Society $\mathrm{B}_{1}$, your monthly income is birr, while the average monthly income of in the society is birr. In which Society, $\mathrm{A}$ or $\mathrm{B}_{1}$, do you want to live? 
(If the respondent chooses $A$, stop and proceed to the next table. If respondent chooses $B_{1}$, ask her/him to choose between Society $A$ and Society $B_{2}$. If respondent chooses $B_{2}$, ask her/him to choose between Society $A$ and $B_{3}$. Continue in a similar manner for the rest of the choices. Do not change the format of the question except for the numbers. Follow the same procedure for the other tables.

Remember! Do not change the order of the tables as it is given in this printout and always start from the first choice in each table!) ${ }^{9}$

Table presenting the choice scenario for reference group 1

Table presenting the choice scenario for reference group 2

Table presenting the choice scenario for reference group 3

Table presenting the choice scenario for reference group 4

Table presenting the choice scenario for reference group 5

Table presenting the choice scenario for reference group 6

\footnotetext{
${ }^{9}$ Instead of presenting six tables for each reference group in the experiment, we thought it is better to present the choice scenario of the 'friends' reference group as an example, given in Table A1 below. The full instructions with all the tables can be requested from the authors.
} 


\begin{tabular}{|c|c|c|}
\hline \multicolumn{3}{|c|}{ Your Friends } \\
\hline Society & $\begin{array}{l}\text { Your own } \\
\text { income } \\
\text { Birr/Month }\end{array}$ & $\begin{array}{l}\text { Average income } \\
\text { of your friends } \\
\text { Birr/Month }\end{array}$ \\
\hline $\mathbf{A}$ & 640 & 720 \\
\hline B1 & 616 & 480 \\
\hline \multicolumn{3}{|c|}{$\begin{array}{l}\text { Which society do you choose to live in? } \\
\text { (Circle choice. If the choies is } A \text {, stop and go to next next page, if the choice is } B_{1} \text {, } \\
\text { proceed below) }\end{array}$} \\
\hline A & 640 & 720 \\
\hline B2 & 592 & 480 \\
\hline \multicolumn{3}{|c|}{$\begin{array}{l}\text { Which society do you choose to live in? } \\
\text { (Circle choice. If the choies is } A \text {, stop and go to next next page, if the choice is } B_{2} \text {, } \\
\text { proceed below) }\end{array}$} \\
\hline A & 640 & 720 \\
\hline B3 & 568 & 480 \\
\hline \multicolumn{3}{|c|}{$\begin{array}{l}\text { Which society do you choose to live in? } \\
\text { (Circle choice. If the choies is A, stop and go to next next page, if the choice is } B_{3} \text {, } \\
\text { proceed below) }\end{array}$} \\
\hline A & 640 & 720 \\
\hline B4 & 544 & 480 \\
\hline \multicolumn{3}{|c|}{$\begin{array}{l}\text { Which society do you choose to live in? } \\
\text { (Circle choice. If the choies is A, stop and go to next next page, if the choice is } B_{4} \text {, } \\
\text { proceed below) }\end{array}$} \\
\hline A & 640 & 720 \\
\hline B5 & 520 & 480 \\
\hline \multicolumn{3}{|c|}{$\begin{array}{l}\text { Which society do you choose to live in? } \\
\text { (Circle choice. If the choies is } A \text {, stop and go to next next page, if the choice is } B_{5} \text {, } \\
\text { proceed below) }\end{array}$} \\
\hline A & 640 & 720 \\
\hline B6 & 496 & 480 \\
\hline \multicolumn{3}{|c|}{$\begin{array}{l}\text { Which society do you choose to live in? } \\
\text { (Circle choice.) }\end{array}$} \\
\hline
\end{tabular}




\section{$\underline{\text { Tables }}$}

Table 1. Summary of the experiment (in ETB).

\begin{tabular}{|c|c|c|c|c|c|c|c|c|c|c|c|c|c|}
\hline & & & & & & & Refer & nce groul & & & & & \\
\hline & & Fri & $n d s$ & $\mathrm{Nei}$ & hbors & Rel & tives & Col & eagues & Same a & people & All oth & r people \\
\hline $\begin{array}{r}\text { Implied } \\
\text { positionality if il }\end{array}$ & $\begin{array}{l}\text { gree of } \\
\text { fferent }\end{array}$ & $\begin{array}{c}\text { Own } \\
\text { income }\end{array}$ & $\begin{array}{c}\text { Friends' } \\
\text { income }\end{array}$ & $\begin{array}{c}\text { Own } \\
\text { income }\end{array}$ & $\begin{array}{l}\text { Neighbors' } \\
\text { income }\end{array}$ & $\begin{array}{c}\text { Own } \\
\text { income }\end{array}$ & $\begin{array}{l}\text { Relatives } \\
\text { income }\end{array}$ & $\begin{array}{c}\text { Own } \\
\text { income }\end{array}$ & $\begin{array}{c}\text { Colleagues' } \\
\text { income }\end{array}$ & $\begin{array}{c}\text { Own } \\
\text { income }\end{array}$ & $\begin{array}{c}\text { Income of } \\
\text { same age } \\
\text { people }\end{array}$ & $\begin{array}{c}\text { Own } \\
\text { income }\end{array}$ & $\begin{array}{c}\text { Income of } \\
\text { all other } \\
\text { people }\end{array}$ \\
\hline Alternative A & & 640 & 720 & 800 & 900 & 760 & 855 & 880 & 990 & 680 & 765 & 824 & 927 \\
\hline Alternative B1 & 0.1 & 616 & 480 & 770 & 600 & 732 & 570 & 847 & 660 & 655 & 510 & 793 & 618 \\
\hline Alternative B2 & 0.2 & 592 & 480 & 740 & 600 & 703 & 570 & 814 & 660 & 629 & 510 & 762 & 618 \\
\hline Alternative B3 & 0.3 & 568 & 480 & 710 & 600 & 675 & 570 & 781 & 660 & 603 & 510 & 731 & 618 \\
\hline Alternative B4 & 0.4 & 544 & 480 & 680 & 600 & 646 & 570 & 748 & 660 & 578 & 510 & 700 & 618 \\
\hline Alternative B5 & 0.5 & 520 & 480 & 650 & 600 & 618 & 570 & 715 & 660 & 553 & 510 & 670 & 618 \\
\hline Alternative B6 & 0.6 & 496 & 480 & 620 & 600 & 589 & 570 & 682 & 660 & 527 & 510 & 640 & 618 \\
\hline \#Subjects & & 260 & & 260 & & 259 & & 260 & & 260 & & 259 & \\
\hline
\end{tabular}


Table 2. Frequency distribution of marginal degree of positionality with alternative reference groups.

\begin{tabular}{|c|c|c|c|c|c|c|c|c|c|c|c|c|}
\hline & \multicolumn{12}{|c|}{ Reference groups } \\
\hline & \multicolumn{2}{|c|}{ Friends } & \multicolumn{2}{|c|}{ Neighbors } & \multicolumn{2}{|c|}{ Relatives } & \multicolumn{2}{|c|}{ Colleagues } & \multicolumn{2}{|c|}{ People of same age } & \multicolumn{2}{|c|}{ All other people } \\
\hline & Freq. & $\%$ & Freq. & $\%$ & Freq. & $\%$ & Freq. & $\%$ & Freq. & $\%$ & Freq. & $\%$ \\
\hline$\gamma<0.1$ & 194 & 74.33 & 181 & 69.35 & 201 & 77.01 & 202 & 77.39 & 199 & 76.25 & 205 & 78.54 \\
\hline $0.1<\gamma<0.2$ & 11 & 4.21 & 23 & 8.81 & 15 & 5.75 & 15 & 5.75 & 8 & 3.07 & 10 & 3.83 \\
\hline $0.2<\gamma<0.3$ & 18 & 6.9 & 14 & 5.36 & 12 & 4.6 & 12 & 4.6 & 19 & 7.28 & 12 & 4.6 \\
\hline $0.3<\gamma<0.4$ & 9 & 3.45 & 13 & 4.98 & 12 & 4.6 & 8 & 3.07 & 8 & 3.07 & 10 & 3.83 \\
\hline $0.4<\gamma<0.5$ & 9 & 3.45 & 5 & 1.92 & 5 & 1.92 & 2 & 0.77 & 9 & 3.45 & 5 & 1.92 \\
\hline $0.5<\gamma<0.6$ & 0 & 0 & 0 & 0 & 1 & 0.38 & 2 & 0.77 & 2 & 0.77 & 2 & 0.77 \\
\hline$\gamma>0.6$ & 19 & 7.28 & 24 & 9.2 & 13 & 4.98 & 19 & 7.28 & 15 & 5.75 & 15 & 5.75 \\
\hline \#Subjects & 260 & & 260 & & 259 & & 260 & & 260 & & 259 & \\
\hline
\end{tabular}


Table 3. Unconditional mean marginal degree of positionality by reference groups.

\begin{tabular}{lccrr}
\hline \hline & mean & standard deviation & \multicolumn{2}{r}{ 95\% confidence interval } \\
& & & lower & upper \\
Friends & 0.151 & 0.221 & 0.124 & 0.178 \\
Neighbors & 0.166 & 0.238 & 0.137 & 0.195 \\
Relatives & 0.129 & 0.192 & 0.105 & 0.152 \\
Colleagues & 0.140 & 0.217 & 0.113 & 0.166 \\
People of the same age & 0.141 & 0.206 & 0.116 & 0.166 \\
All other people in Addis & 0.133 & 0.203 & 0.108 & 0.157 \\
Overall & 0.141 & 0.134 & 0.125 & 0.158 \\
\hline
\end{tabular}


Table 4. Interval regression estimation results by alternative reference groups.

Dependent variable=intervals of marginal degree of positionality

Reference groups

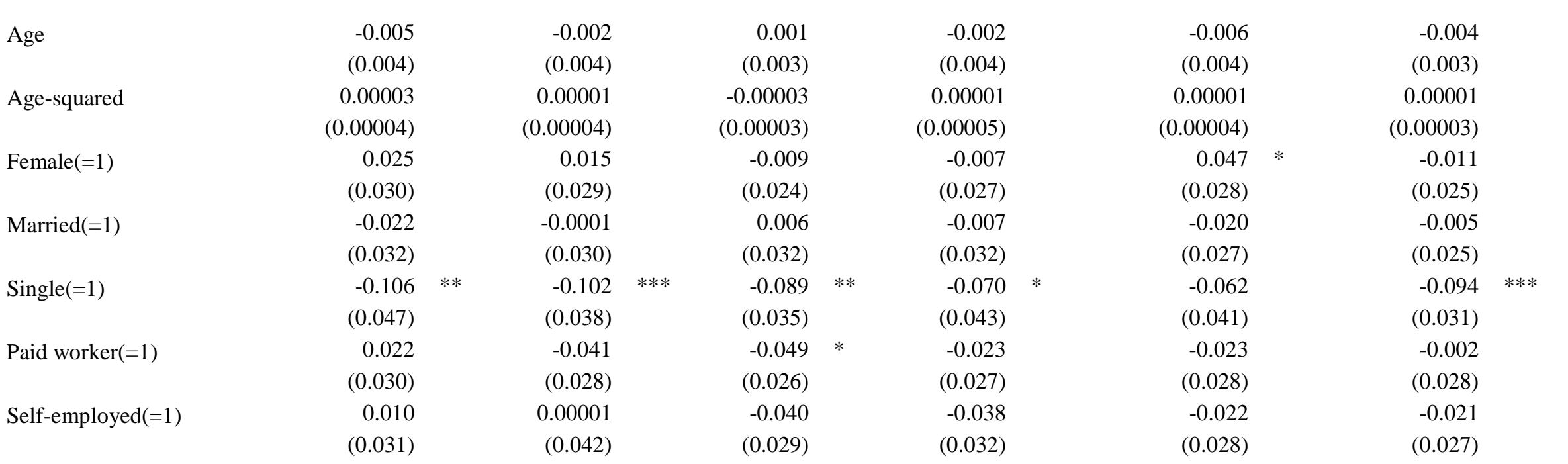




\begin{tabular}{|c|c|c|c|c|c|c|c|c|c|c|c|c|}
\hline Secondary education & $\begin{array}{r}0.034 \\
(0.031)\end{array}$ & & $\begin{array}{r}0.074 \\
(0.033)\end{array}$ & $* *$ & $\begin{array}{r}-0.008 \\
(0.027)\end{array}$ & & $\begin{array}{r}0.062 \\
(0.032)\end{array}$ & * & $\begin{array}{r}0.053 \\
(0.030)\end{array}$ & $*$ & $\begin{array}{r}-0.019 \\
(0.030)\end{array}$ & \\
\hline High education & $\begin{array}{r}0.014 \\
(0.035)\end{array}$ & & $\begin{array}{r}0.094 \\
(0.041)\end{array}$ & $* *$ & $\begin{array}{r}-0.012 \\
(0.029)\end{array}$ & & $\begin{array}{r}0.038 \\
(0.035)\end{array}$ & & $\begin{array}{r}0.000 \\
(0.024)\end{array}$ & & $\begin{array}{r}-0.026 \\
(0.033)\end{array}$ & \\
\hline Migrant to Addis & $\begin{array}{r}0.012 \\
(0.023)\end{array}$ & & $\begin{array}{r}-0.029 \\
(0.024)\end{array}$ & & $\begin{array}{r}-0.013 \\
(0.022)\end{array}$ & & $\begin{array}{r}0.011 \\
(0.025)\end{array}$ & & $\begin{array}{r}0.031 \\
(0.023)\end{array}$ & & $\begin{array}{r}-0.027 \\
(0.024)\end{array}$ & \\
\hline Log (household size) & $\begin{array}{r}-0.044 \\
(0.023)\end{array}$ & $*$ & $\begin{array}{r}0.007 \\
(0.020)\end{array}$ & & $\begin{array}{r}0.008 \\
(0.016)\end{array}$ & & $\begin{array}{r}0.032 \\
(0.022)\end{array}$ & & $\begin{array}{r}0.016 \\
(0.020)\end{array}$ & & $\begin{array}{r}-0.005 \\
(0.018)\end{array}$ & \\
\hline Log (household income) & $\begin{array}{r}-0.015 \\
(0.008)\end{array}$ & $*$ & $\begin{array}{r}-0.026 \\
(0.011)\end{array}$ & $* *$ & $\begin{array}{r}-0.007 \\
(0.007)\end{array}$ & & $\begin{array}{r}-0.012 \\
(0.009)\end{array}$ & & $\begin{array}{r}-0.013 \\
(0.008)\end{array}$ & & $\begin{array}{r}0.001 \\
(0.007)\end{array}$ & \\
\hline Other income $(=1)$ & $\begin{array}{r}-0.015 \\
(0.022)\end{array}$ & & $\begin{array}{r}-0.026 \\
(0.027)\end{array}$ & & $\begin{array}{r}-0.002 \\
(0.022)\end{array}$ & & $\begin{array}{r}0.012 \\
(0.026)\end{array}$ & & $\begin{array}{r}-0.005 \\
(0.023)\end{array}$ & & $\begin{array}{r}0.020 \\
(0.021)\end{array}$ & \\
\hline Constant & $\begin{array}{r}0.415 \\
(0.155)\end{array}$ & $* * *$ & $\begin{array}{r}0.412 \\
(0.155)\end{array}$ & $* * *$ & $\begin{array}{r}0.274 \\
(0.143)\end{array}$ & $*$ & $\begin{array}{r}0.284 \\
(0.138)\end{array}$ & $* *$ & $\begin{array}{r}0.319 \\
(0.142)\end{array}$ & $* *$ & $\begin{array}{r}0.283 \\
(0.134)\end{array}$ & $* *$ \\
\hline Regions in Addis (a) & yes & & yes & & yes & & yes & & yes & & yes & \\
\hline Ethnic group in Addis (b) & yes & & yes & & yes & & yes & & yes & & yes & \\
\hline Prob>chi-squared & 0.003 & & 0.017 & & 0.003 & & 0.390 & & 0.017 & & 0.059 & \\
\hline Sigma & $\begin{array}{r}0.161 \\
(0.011)\end{array}$ & $* * *$ & $\begin{array}{r}0.175 \\
(0.013)\end{array}$ & $* * *$ & $\begin{array}{r}0.145 \\
(0.012)\end{array}$ & $* * *$ & $\begin{array}{r}0.164 \\
(0.014)\end{array}$ & $* * *$ & $\begin{array}{r}0.154 \\
(0.012)\end{array}$ & $* * *$ & $\begin{array}{r}0.152 \\
(0.013)\end{array}$ & $* * *$ \\
\hline $\begin{array}{l}\text { Pseudo-loglikelihood } \\
\text { \#obs }\end{array}$ & $\begin{array}{r}-483.072 \\
258\end{array}$ & & $\begin{array}{r}-499.356 \\
258\end{array}$ & & $\begin{array}{r}-460.424 \\
257\end{array}$ & & $\begin{array}{r}-488.155 \\
258\end{array}$ & & $\begin{array}{r}-475.957 \\
258\end{array}$ & & $\begin{array}{r}-471.689 \\
257\end{array}$ & \\
\hline
\end{tabular}

Notes: The upper limit is assumed to be 1 and lower limit is assumed to be 0 in the interval regressions;

(a) there are 5 regions in our sample: Kirkos, Arada, Addis Ketama, Yeka, Gullele (Kirkos is excluded);

(b) there are 4 ethnic classifications: Amhara, Oromo, Tigray and Others (Amhara is excluded);

$[*],[* *]$, and $[* * *]$ indicate significance at $10 \%, 5 \%$, and $1 \%$ level. 
Table 5. Marginal degree of positional concerns: 1,000 bootstrap estimates and confidence intervals with percentile method.

\begin{tabular}{|c|c|c|c|c|c|c|c|c|}
\hline \multirow{3}{*}{ All } & \multicolumn{8}{|c|}{ Reference groups } \\
\hline & \multirow[t]{2}{*}{ Friends } & \multirow[t]{2}{*}{ Neighbors } & \multicolumn{2}{|l|}{ Relatives } & \multirow[t]{2}{*}{ Colleagues } & \multicolumn{2}{|c|}{ People of same age } & All other people \\
\hline & & & & & & & & \\
\hline MDPC & 0.073 & 0.003 & 0.056 & & 0.070 & 0.147 & $*$ & 0.018 \\
\hline std.err. & $(0.088)$ & $(0.091)$ & $(0.071)$ & & $(0.073)$ & $(0.081)$ & & $(0.074)$ \\
\hline PCI & $(-0.026,0.322)$ & $(-0.012,0.363)$ & $(-0.011,0.263)$ & & $(-0.012,0.277)$ & $(-0.012,0.298)$ & & $(-0.018,0.275)$ \\
\hline \multicolumn{9}{|l|}{ Males } \\
\hline MDPC & 0.071 & -0.005 & 0.122 & & 0.141 & 0.107 & & 0.031 \\
\hline std.err. & $(0.111)$ & $(0.124)$ & $(0.088)$ & & $(0.116)$ & $(0.088)$ & & $(0.108)$ \\
\hline PCI & $(-0.039,0.364)$ & $(-0.068,0.446)$ & $(-0.054,0.299)$ & & $(-0.056,0.412)$ & $(-0.040,0.297)$ & & $(-0.069,0.350)$ \\
\hline \multicolumn{9}{|l|}{ Females } \\
\hline MDPC & 0.144 & 0.052 & 0.054 & & 0.023 & 0.271 & $* *$ & 0.048 \\
\hline std.err. & $(0.113)$ & $(0.115)$ & $(0.091)$ & & $(0.095)$ & $(0.109)$ & & $(0.090)$ \\
\hline PCI & $(-0.039,0.408)$ & $(-0.031,0.439)$ & $(-0.035,0.336)$ & & $(-0.039,0.316)$ & $(-0.045,0.397)$ & & $(-0.042,0.307)$ \\
\hline \multicolumn{9}{|c|}{ Employed/Self-employed } \\
\hline MDPC & 0.018 & -0.039 & 0.070 & & 0.078 & 0.127 & & 0.002 \\
\hline std.err. & $(0.120)$ & $(0.115)$ & $(0.086)$ & & $(0.091)$ & $(0.084)$ & & $(0.103)$ \\
\hline PCI & $(-0.055,0.420)$ & $(-0.052,0.403)$ & $(-0.028,0.327)$ & & $(-0.042,0.340)$ & $(-0.034,0.299)$ & & $(-0.044,0.344)$ \\
\hline \multicolumn{9}{|c|}{ Unemployed } \\
\hline MDPC & 0.110 & 0.045 & 0.022 & & 0.054 & 0.159 & & 0.036 \\
\hline std.err. & $(0.098)$ & $(0.109)$ & $(0.090)$ & & $(0.107)$ & $(0.118)$ & & $(0.090)$ \\
\hline PCI & $(-0.039,0.355)$ & $(-0.023,0.412)$ & $(-0.026,0.324)$ & & $(-0.036,0.404)$ & $(-0.039,0.442)$ & & $(-0.055,0.320)$ \\
\hline \multicolumn{9}{|l|}{ Married } \\
\hline MDPC & 0.171 & 0.116 & 0.335 & $\begin{array}{l}* * \\
*\end{array}$ & 0.135 & 0.395 & $* * *$ & 0.218 \\
\hline std.err. & $(0.123)$ & $(0.150)$ & (0.119) & & $(0.136)$ & $(0.107)$ & & $(0.122)$ \\
\hline PCI & $(-0.064,0.435)$ & $(-0.082,0.524)$ & $(-0.0412,0.401)$ & & $(-0.083,0.464)$ & $(-0.053,0.381)$ & & $(-0.052,0.413)$ \\
\hline
\end{tabular}




\begin{tabular}{|c|c|c|c|c|c|c|c|}
\hline \multicolumn{8}{|l|}{ Single } \\
\hline MDPC & 0.035 & 0.014 & 0.033 & 0.131 & 0.102 & & -0.010 \\
\hline std.err. & $(0.093)$ & $(0.092)$ & $(0.077)$ & $(0.090)$ & $(0.114)$ & & $(0.084)$ \\
\hline PCI & $(-0.041,0.322)$ & $(-0.042,0.348)$ & $(-0.041,0.288)$ & $(-0.028,0.328)$ & $(-0.049,0.391)$ & & $(-0.050,0.289)$ \\
\hline \multicolumn{8}{|c|}{ Widowed/Divorced } \\
\hline MDPC & 0.172 & -0.165 & 0.079 & 0.111 & 0.159 & & 0.101 \\
\hline std.err. & $(0.150)$ & $(0.129)$ & $(0.105)$ & $(0.137)$ & $(0.130)$ & & $(0.120)$ \\
\hline PCI & $(-0.080,0.539)$ & $(-0.041,0.459)$ & $(-0.059,0.365)$ & $(-0.083,0.476)$ & $(-0.073,0.448)$ & & $(-0.077,0.389)$ \\
\hline \multicolumn{8}{|c|}{ No education } \\
\hline MDPC & 0.148 & 0.125 & 0.084 & 0.081 & 0.253 & $* *$ & 0.153 \\
\hline std.err. & $(0.103)$ & $(0.101)$ & $(0.085)$ & $(0.094)$ & $(0.100)$ & & $(0.102)$ \\
\hline PCI & $(-0.041,0.377)$ & $(-0.042,0.364)$ & $(-0.025,0.318)$ & $(-0.041,0.339)$ & $(-0.046,0.364)$ & & $(-0.047,0.356)$ \\
\hline \multicolumn{8}{|c|}{ Middle education } \\
\hline MDPC & 0.110 & -0.038 & 0.072 & 0.213 & 0.232 & $*$ & 0.048 \\
\hline std.err. & $(0.132)$ & $(0.146)$ & $(0.110)$ & $(0.135)$ & $(0.128)$ & & $(0.116)$ \\
\hline PCI & $(-0.041,0.435)$ & $(-0.082,0.522)$ & $(-0.064,0.392)$ & $(-0.063,0.533)$ & $(-0.048,0.347)$ & & $(-0.069,0.403)$ \\
\hline \multicolumn{8}{|c|}{ High education } \\
\hline MDPC & 0.047 & 0.008 & 0.041 & 0.004 & 0.052 & & -0.043 \\
\hline std.err. & $(0.155)$ & $(0.184)$ & $(0.107)$ & $(0.145)$ & $(0.137)$ & & $(0.116)$ \\
\hline PCI & $(-0.090,0.548)$ & $(-0.067,0.666)$ & $(-0.070,0.410)$ & $(-0.075,0.510)$ & $(-0.054,0.526)$ & & $(-0.043,0.412)$ \\
\hline
\end{tabular}

Notes: Each result is obtained using 1,000 bootstrap replications to interval regressions;

MDPC is the marginal degree of positional concern;

Std.err. is the bootstrap standard error and PCI is the percentile method confidence intervals;

$[*],[* *]$,and $[* * *]$ indicate significance at $10 \%, 5 \%$, and $1 \%$ level. 